\title{
PENGARUH UKURAN PERUSAHAAN, KEBIJAKAN HUTANG, PROFITABILITAS, LIKUIDITAS TERHADAP KEBIJAKAN DIVIDEN PADA PERUSAHAAN WHOLESALE/RETAIL DI BURSA EFEK INDONESIA
}

\section{EFFECT OF COMPANY SIZE, DEBT POLICY, PROFITABILITY, LIQUIDITY AGAINST DIVIDEND POLICY IN COMPANIES WHOLESALE/RETAIL IN INDONESIA EXCHANGE}

\author{
Angeline Setiawan', Liyi Sumira Purba², \\ Annisa Nauli Sinaga ${ }^{3}$, Sherly Estenia ${ }^{4}$ \\ Universitas Prima Indonesia ${ }^{1,2,3,4}$ \\ angelinesetiawan@gmail.com ${ }^{1}$
}

\begin{abstract}
The purpose of this study was to examine and analyze how the influence of Company Size, Debt Policy, Profitability, Liquidity Against Dividend Policy in Wholesale / Retail Companies Listed on the Indonesia Stock Exchange Period 2015-2019. The research method uses quantitative and descriptive approaches. The population in this study is the overall number of Wholesale / Retail sector companies listed on the Indonesia Stock Exchange, amounting to 63 companies. The sample of this study were 11 companies with a purposive sampling method. The data analysis technique is multiple linear regression analysis. Partially shows that profitability has a positive and significant effect on dividend policy on Wholesale / Retail companies listed on the Indonesia Stock Exchange in the 2015-2019 period. While Company Size, Debt Policy, Liquidity have no effect and are not significant on dividend policy at Wholesale / Retail companies listed on the Indonesia Stock Exchange for the period of 2015-2019. And simultaneously Company Size, Debt Policy, Profitability, Liquidity have significant and significant effect on dividend policy on Wholesale / Retail companies listed on the Indonesia Stock Exchange for the period of 2015-2019. The magnitude of the coefficient of determination is $29.2 \%$ while the remaining $70.8 \%$ dividend policy is explained by other variables not examined in this study. The conclusion of this study is that partially only profitability has a positive and significant effect on dividend policy on Wholesale I Retail companies listed on the Indonesia Stock Exchange in the period 2015-2019.
\end{abstract}

Keywords: Company Size, Debt Policy, Profitability, Liquidity, and Dividend Policy

\begin{abstract}
ABSTRAK
Tujuan penelitian ini untuk menguji dan menganalisis bagaimana pengaruh Ukuran Perusahaan, Kebijakan Hutang, Profitabilitas, Likuiditas Terhadap Kebijakan Dividen Pada Perusahaan Wholesale/Retail Yang Terdaftar Di Bursa Efek Indonesia Periode 2015-2019. Metode penelitian menggunakan pendekatan kuantitatif dan deskriptif. Populasi dalam penelitian ini adalah keseluruhan jumlah perusahaan sektor Wholesale/Retail yang terdaftar di Bursa Efek Indonesia yang berjumlah 63 perusahaan. Sampel penelitian ini sebanyak 11 perusahaan dengan metode purposive sampling. Teknik analisis data adalah analisis regresi linear berganda. Secara parsial menunjukkan bahwa profitabilitas berpengaruh positif dan signifikan terhadap kebijakan dividen pada perusahaan Wholesale/Retail yang terdaftar di Bursa Efek Indonesia periode 2015-2019.
\end{abstract}


Sedangkan Ukuran Perusahaan, Kebijakan Hutang, Likuiditas tidak berpengaruh dan tidak signifikan terhadap kebijakan dividen pada perusahaan Wholesale/Retail yang terdaftar di Bursa Efek Indonesia periode 2015-2019. Dan secara simultan Ukuran Perusahaan, Kebijakan Hutang,Profitabilitas,Likuiditas berpengaruh dan signifikan terhadap kebijakan dividen pada perusahaan Wholesale/Retail yang terdaftar di Bursa Efek Indonesia periode 2015-2019. Besarnya koefisien determinasi sebesar 29,2\% sedangkan sisanya sebesar 70,8\% kebijakan dividen dijelaskan oleh variabel lain yang tidak diteliti dalam penelitian ini. Kesimpulan penelitian ini adalah secara parsial hanya profitabilitas berpengaruh positi dan signifikan terhadap kebijakan dividen pada perusahaan Wholesale/Retail yang terdaftar di Bursa Efek Indonesia periode 2015-2019.

Kata Kunci : Ukuran Perusahaan, Kebijakan Hutang, Profitabilitas, Likuiditas, dan Kebijakan Dividen

\section{PENDAHULUAN}

Saat ini perkembangan pasar modal di Indonesia menyebabkan banyaknya persaingan yang terjadi antara perusahaan-perusahaan sektor Wholesale/Retail. Persaingan yang efektif ini menuntut setiap perusahaan untuk meningkatkan potensi dan peluang yang ada secara efektif dan efisien dalam kegiatan operasionalnya agar dapat meningkatkan kinerja perusahaan terutama dalam hal kebijakan dividen. Untuk menentukan kebijakan dividen tidaklah mudah karena perusahaan harus tergantung pada besarnya laba yang diperoleh. Jika laba perusahaan mengalami peningkatan maka secara otomatis deviden yang akan dibagikan oleh perusahaan kepada para pemegang saham juga akan semakin besar jumlahnya.

Hal inilah yang perlu diwaspadai karena tidak semua perusahaan mampu memberikan dividen karena perusahaan selalu memperhatikan saldo laba yang akan digunakan untuk membiayai operasional perusahaan. Untuk itulah sangat penting bagi perusahaan dalam mempertimbangkan kebijakan devidennya agar para investor tetap menanamkan sahamnya di perusahaan tersebut.

Pendekatan yang dilakukan untuk menentukan kebijakan dividen atau dividend payout ratio (DPR) pada penelitian ini dapat dilihat pada ukuran perusahaan, kebijakan hutang, profitabilitas dan likuiditas. Ukuran perusahaan memberikan gambaran besar kecilnya perusahaan. Semakin besar ukuran perusahaan berarti perusahaan mampu meningkatkan aset perusahaan sehingga dapat berdampak pada peningkatan pembagian dividen perusahaan sedangkan sebaliknya semakin kecil ukuran perusahaan berarti perusahaan dianggap kurang mampu meningkatkan aset perusahaan sehingga dapat berdampak pada penurunan pembagian dividen perusahaan.

Kebijakan hutang memberi informasi tentang kemampuan perusahaan untuk membayar hutang perusahaan. Kebijakan hutang dapat dilihat pada Debt To Asset Ratio. Semakin besar kebijakan utang berarti perusahaan memiliki tingkat resiko yang tinggi dalam membayar total hutang perusahaan sehingga berdampak pada penurunan pembayaran dividen kepada pemegang saham sedangkan sebaliknya semakin kecil kebijakan utang berarti perusahaan dianggap mampu membayar total hutang perusahaan sehingga berdampak pada peningkatan pembayaran dividen kepada pemegang saham

Profitabilitas menggambarkan tingkat keuntungan yang diperoleh 
perusahaan. Profitabilitas penelitian ini menggunakan Return On Invesment. Semakin besar Return On Invesment berarti perusahaan memperoleh keuntungan yang besar sehingga berdampak pada peningkatan pembagian dividen perusahaan sedangkan sebaliknya semakin kecil Return On Invesment berarti perusahaan memperoleh keuntungan yang kecil sehingga berdampak pada penurunan pembagian dividen perusahaan.

Likuiditas menggambarkan kemampuan pembayaran hutang jangka pendek. Likuiditas penelitian ini menggunakan Current Ratio. Semakin tinggi Current Ratio perusahaan berarti perusahaan mampu membayar hutang yang telah jatuh tempo sehingga berdampak pada peningkatan pembagian dividen kepada pemegang saham sedangkan sebaliknya semakin kecil Current Ratio berarti perusahaan dianggap tidak mampu membayar hutang yang telah jatuh tempo sehingga berdampak pada penurunan pembagian dividen kepada pemegang saham.

Anggraini \& Wihandaru (2015) berpendapat bahwa perusahaan besar kemungkinan membayar dividen lebih besar. Hal ini dikarenakan perusahaan besar memiliki kemudahaan akses dalam memperoleh hutang, selain iu perusahaan besar mampu memperoleh laba yang besar dari aset yang dimiliki.

Selanjutnya Arjana \& Suputra (2017) berpendapat bahwa perusahaan besar mereka akan memiliki kecenderungan untuk membagikan dividen dalam jumlah tinggi untuk menjaga reputasi perusahaan dimata para investor. Sedangkan perusahaan kecil cenderung akan mengalokasikan laba yang diperoleh menjadi laba ditahan untuk meningkatkan aset perusahaan sehingga membuat perusahaan cenderung akan membagikan dividen yang rendah kepada investor.
Dhira, et.al (2014) berpendapat bahwa perusahaan yang sudah mapan atau dewasa yang dicirikan dengan ukuran perusahaan yang relatif besar baik dalam bentuk total asset atau penjualan, kebijakan dividennya akan lebih banyak berorientasi atau berpihak kepada pemegang saham.

Dari ketiga pendapat di atas disimpulkan bahwa semakin besar perusahaan cenderung mampu memperoleh laba yang besar sehingga meningkatkan pembagian dividen dan sebaliknya semakin kecil perusahaan cenderung memiliki laba yang kecil sehingga menurunkan pembagian dividen. Thaib \& Taroreh (2015) berpendapat bahwa semakin rendah tingkat hutang dari perusahaan maka akan semakin tinggi kemampuan perusahaan untuk membayar seluruh kewajibannya pada pihak kreditur dan semakin tinggi juga kemampuan perusahaan untuk memenuhi kewajibannya pada para pemegang saham.

Hery (2017) mengatakan bahwa perusahaan yang memiliki utang yang tinggi akan memberikan dividen yang rendah. Jika utang perusahaan semakin meningkat maka kemampuan perusahaan untuk membayar dividen kepada pemegang saham akan semakin menurun. Musthafa (2017) mengatakan bahwa kalau perusahaan akan melunasi hutangnya dengan segera maka dividen bisa kecil atau laba ditahan, dan sebaliknya kalau perusahaan tidak segera melunasi hutangnya atau tidak ada hutang yang dibayar, maka dividen bisa dibayar cukup besar oleh perusahaan dari keuntungan yang diperoleh.

Dari ketiga pendapat di atas disimpulkan bahwa semakin kecil hutang atau tidak ada hutang yang dibayar akan dapat meningkatkan dividen dan sebaliknya semakin besar hutang cenderung memberikan risiko 
kebangkrutan yang besar sehingga dapat menurunkan dividen. Bansaleng, et.al (2014) berpendapat bahwa semakin tinggi profitabilitas yang dihasilkan perusahaan, maka akan semakin tinggi pula dividen yang dapat dibayarkan perusahaan kepada para pemegang sahamnya. Sebaliknya, semakin rendah profitabilitas yang dihasilkan perusahaan maka akan semakin rendah pula dividen yang dapat dibayarkan perusahaan. Hal ini tentu akan berdampak buruk bagi para pemegang saham dengan kepentingan dividennya.

Selanjutnya Husnan \&

Pudjiastuti (2012) mengatakan bahwa peningkatan pembayaran dividen hanya dimungkinkan apabila laba yang diperoleh oleh perusahaan juga meningkat. Perusahaan yang tidak bisa membagikan dividen yang makin besar apabila laba yang diperoleh tidak meningkat. Mulyawan (2015) mengatakan bahwa profitabilitas yang baik bisa membayar dividen atau meningkatkan dividend. Demikian pula sebaliknya profitabilitas yang buruk tidak bisa meningkatkan dividen.

Dari ketiga pendapat di atas disimpulkan bahwa semakin besar profitabilitas maka dividen yang dibagikan meningkat dan semakin kecil profitabilitas maka perusahaan tidak akan dapat meningkatkan dividen. Saputra (2013) berpendapat bahwa deviden merupakan arus kas keluar, maka semakin besar posisi kas dan likuiditas menyeluruh dari perusahaan, semakin besar kemampuan untuk membayar deviden. Sudana (2015) mengatakan bahwa semakin tinggi tingkat likuiditas perusahaan, semakin besar dividen tunai yang mampu dibayar perusahaan kepada pemegang saham, dan sebaliknya.

Musthafa (2017) mengatakan bahwa kalau likuiditas perusahaan baik, dividen dapat dibagikan lebih besar, begitu pula sebaliknya apabila likuiditas perusahaan tidak baik, maka dividen bisa kecil atau bisa tidak dibagikan sebagai dividen tetapi ditahan oleh perusahaan yang disebut laba ditahan.

Dari ketiga pendapat di atas disimpulkan bahwa semakin tinggi likuiditas, maka semakin besar juga dividen yang dibayarkan dan sebaliknya semakin rendah likuiditas, maka semakin kecil juga dividen yang mampu dibayarkan.

\section{METODE PENELITIAN}

Penelitian ini menggunakan pendekatan kuantitatif dan deskriptif. Hal ini dikarenakan penelitian ini ingin mengetahui nilai masing-masing variabel, baik satu variabel atau lebih sifatnya independen tanpa membuat hubungan maupun perbandingan dengan variabel lain.

\section{Populasi dan Sampel Penelitian}

Populasi yang digunakan adalah keseluruhan jumlah perusahaan sektor Wholesale/Retail yang terdaftar di Bursa Efek Indonesia yang berjumlah 63 perusahaan. Penelitian ini menggunakan teknik purposive sampling.

\section{Teknik Analisis Data Analisis Regresi Linear Berganda}

Metode analisis data yang digunakan adalah analisis regresi linier berganda. Model regresi yang digunakan adalah sebagai berikut:

$$
\mathbf{Y}=\mathbf{a}-\mathbf{b}_{1} \mathbf{X}_{1}+\mathbf{b}_{2} \mathbf{X}_{2}+\mathbf{b}_{3} \mathbf{X}_{3}+\mathbf{b}_{4} \mathbf{X}_{4}+\mathbf{e}
$$

Keterangan:

$\mathrm{Y}=$ Kebijakan Dividen

a $\quad$ Konstanta

$\mathrm{b}_{1}=$ Koefisien Regresi Variabel X1 (Ukuran Perusahaan)

$\mathrm{b}_{2} \quad=$ Koefisien Regresi Variabel X2 (Kebijakan Hutang)

$\mathrm{b}_{3}=$ Koefisien Regresi Variabel X3 (Profitabilitas)

$\mathrm{b}_{4}=$ Koefisien Regresi Variabel X4 
(Likuiditas)

$\mathrm{X}_{1} \quad=$ Variabel Ukuran Perusahaan

$\mathrm{X}_{2}=$ Variabel Kebijakan Hutang

$\mathrm{X}_{3}=$ Variabel Prifitabilitas

$\mathrm{X}_{4} \quad=$ Variabel Likuiditas

$\mathrm{e} \quad=$ Persentase

\section{Koefisien Determinasi Hipotesis \\ Koefisien determinasi}

bertujuan untuj mengukur seberapa jauh kemampuan model dalam menerangkan variasi variabel dependen.

\section{Pengujian Hipotesis (Uji F)}

Uji statistisk $F$ pada dasarnya menunjukan apakah semua variabel independen atau bebas yang dimaksukan dalam model mempunyai pengaruh secara bersama-sama terhadap variabel dependen/terikat.

\section{Pengujian Hipotesis (Uji t)}

Uji Statistik t pada dasarnya menunjukan seberapa jauh pengaruh variabel independen secara individual menjelaskan variabel dependen.

\section{HASIL DAN PEMBAHASAN Model Penelitian}

Model analisis penelitian ini adalah analisis persamaan regresi linier berganda sebagai berikut :

\begin{tabular}{|c|c|c|c|}
\hline Tabel.1 & $\begin{array}{l}\text { Hasil Analisis } \\
\text { Berganda }\end{array}$ & Regresi & Linier \\
\hline \multirow{2}{*}{\multicolumn{2}{|c|}{ Model }} & \multicolumn{2}{|c|}{$\begin{array}{c}\text { Unstandardized } \\
\text { Coefficients }\end{array}$} \\
\hline & & $\mathrm{B}$ & Std. Error \\
\hline (Constan & & -4.136 & 3.040 \\
\hline$\overline{\text { SQRT_L }}$ & Jkuranperus & .782 & .501 \\
\hline SQRT_k & ebijakanhutang & .217 & .629 \\
\hline$\overline{\mathrm{SQRT} \_\mathrm{p}}$ & rofitabilitas & 1.078 & .265 \\
\hline$\overline{\text { SQRT_li }}$ & ikuiditas & .031 & .185 \\
\hline
\end{tabular}

adalah :

Penjelasan dari persamaan diatas

1. Nilai konstanta $a=-4,136$. Nilai konstanta ini, menunjukkan bahwa apabila nilai variabel bebas yaitu ukuran perusahaan, kebijakan hutang, profitabilitas, likuiditas bernilai konstan, maka nilai struktur modal tetap sebesar - 4,136.

2. Nilai koefisien $b 1=0,782$ pada variable Ukuran Perusahaan. Koefisien regresi ini, menunjukkan bahwa setiap kenaikan variabel ukuran perusahaan sebesar 1 satuan, maka nilai struktur modal pada perusahaan WholeSale/Retail Yang Terdaftar di Bursa Efek Indonesia Periode 2015 - 2019 akan mengalami peningkatan sebesar 0,782 kali satuan dengan asumsi variabel lain dianggap tetap.

3. Nilai koefisien b2 $=0,217$ pada variabel Kebijakan Hutang. Koefisien regresi ini menunjukkan bahwa setiap kenaikan variabel kebijakan hutang sebesar 1 satuan, maka nilai struktur modal pada perusahaan WholeSale/Retail Yang Terdaftar di Bursa Efek Indonesia Periode 2015 - 2019 akan mengalami peningkatan sebesar 0,217 kali satuan dengan asumsi variabel lain dianggap tetap.

4. Nilai koefisien b3 $=1,078$ pada variable Profitabilitas. Koefisien regresi ini menunjukkan bahwa setiap penurunan variabel profitabilitas sebesar 1 satuan, maka nilai struktur modal pada perusahaan WholeSale/Retail Yang Terdaftar di Bursa Efek Indonesia Periode 2015 - 2019 akan mengalami peningkatan sebesar 01,078 kali satuan dengan asumsi variabel lain dianggap tetap.

5. Nilai koefisien b4 $=0,031$ pada variabel Likuiditas. Koefisien regresi ini menunjukkan bahwa setiap penurunan variabel likuiditas sebesar 1 satuan, maka nilai struktur modal pada perusahaan WholeSale/Retail Yang Terdaftar di 
Bursa Efek Indonesia Periode 2015 - 2019 akan mengalami penurunan sebesar 0,031 kali satuan dengan asumsi variabel lain dianggap tetap.

\section{Koefisien Determinasi (R2)}

Koefisien determinasi berfungsi untuk menjelaskan sejauh apa seluruh variabel independen dapat menjelaskan variabel dependen. Apabila R2 sama dengan nol, maka variasi variabel independen yang digunakan dalam model tidak menjelaskan sedikitpun variasi variabel independen.

Tabel 2 Koefisien Determinasi

\begin{tabular}{llcr}
\hline & & \multicolumn{2}{c}{$\begin{array}{c}\text { Adjusted R } \\
\text { Model }\end{array}$} \\
R & R Square & Square \\
\hline 1 & $.540^{\mathrm{a}}$ & .292 & .235 \\
\hline Sumber : Olahan Data SPSS (2020)
\end{tabular}

Dari tabel diketahui bahwa pengaruh variabel independen terhadap variabel dependen dinyatakan dengan koefisien determinasi $\mathrm{R}$ square yaitu sebesar 0,292. Hal ini berarti 29,2\% kebijakan dividen dapat dijelaskan oleh variasi dari keempat variabel independen yaitu ukuran perusahaan, kebijakan hutang, profitabilitas, dan likuiditas. Sedangkan sisanya sebesar $70,8 \%$ dijelaskan oleh faktor-faktor lain yang tidak diteliti.

\section{Pengujian Hipotesis Secara Simultan (Uji F) \\ Pengujian Hipotesis Secara} Simultan (Uji F) Uji F digunakan untuk menguji apakah variabel independen secara bersama-sama mempengaruhi variabel dependen. Berdasarkan hasil penelitian dengan program SPSS, maka diperoleh hasil uji F sebagai berikut :
Tabel 3 Hasil Uji F

\begin{tabular}{llll}
\hline Model & & F & Sig. \\
\hline \multirow{2}{*}{1} & Regression & 5.153 & $.001^{\text {a }}$ \\
\cline { 2 - 4 } & Residual & & \\
\cline { 2 - 3 } & Total & & \\
\multicolumn{3}{l}{ Sumber : Olahan Data SPSS (2020) } & \\
& Berdasarkan penelitian & yang
\end{tabular}
telah dilakukan dengan uji ANOVA atau Ftabel dan didapatkan hasil nilai Fhitung sebesar 5,153 dengan probabilitas 0,01 . Karena probabilitas lebih kecil dari 0,05 dan nilai Fhitung lebih besar dari nilai Ftabel yang sebesar 2,5571, maka dari data setelah transformasi, model regresi dapat digunakan untuk memprediksi ukuran perusahaan, kebijakan hutang, profitabilitas dan likuiditas bisnis secara bersama-sama berpengaruh terhadap kebijakan dividen. Pengujian Hipotesis Secara Parsial

\section{Pengujian Hipotesis Secara Parsial (Uji T)}

Pengujian Hipotesis Secara Parsial (Uji T) Uji T digunakan untuk menguji apakah variabel independen secara individual mempengaruhi variabel dependen. Berdasarkan hasil pengolahan data dengan program SPSS, maka diperoleh hasil uji $t$ sebagai berikut :

Tabel 4 Hasil (Uji t)

\begin{tabular}{ccc} 
Model & $\mathrm{t}$ & Sig. \\
\hline SQRT_Ukuranperus & 1.562 & .125 \\
\hline $\begin{array}{c}\text { SQRT_kebijakanhut } \\
\text { ang }\end{array}$ & .345 & .732 \\
\hline SQRT_profitabilitas & 4.068 & .000 \\
\hline SQRT_likuiditas & .168 & .867 \\
\hline
\end{tabular}

Sumber : Olahan Data SPSS (2020) 
Dari tabel setelah transformasi, dapat dijelaskan hasil pengujian hipotesis secara parsial sebagai berikut:

1. Pengujian hipotesis secara parsial (Uji-t) untuk ukuran perusahaan terhadap kebijakan dividen adalah nilai thitung sebesar 1,562, sedangkan nilai t tabel sebesar 2,208 maka $\mathrm{t}$ hitung $<\mathrm{t}$ tabel $(1,562<$ 2,208) dengan nilai signifikansi < 0,05 yang berarti bahwa ukuran perusahaan tidak berpengaruh dan tidak signifikan terhadap kebijakan dividen pada Perusahaan WholeSale/Retail Yang Terdaftar di Bursa Efek Indonesia Periode 2015 $-2019$.

2. Pengujian hipotesis secara parsial untuk kebijakan hutang terhadap kebijakan dividen adalah nilai $\mathrm{t}$ hitung sebesar 0,345, sedangkan nilai $\mathrm{t}$ tabel sebesar 2,208 maka $\mathrm{t}$ hitung $<\mathrm{t}$ tabel $(0,345<2,208)$ dengan nilai signifikansi $>0,05$ yang berarti bahwa kebijakan hutang tidak berpengaruh dan tidak signifikan terhadap kebijakan dividen pada Perusahaan WholeSale/Retail Yang Terdaftar di Bursa Efek Indonesia Periode 2015 $-2019$.

3. Pengujian hipotesis secara parsial (Uji-t) untuk profitabilitas terhadap kebijakan dividen adalah nilai $\mathrm{t}$ hitung sebesar 4,068, sedangkan nilai $\mathrm{t}$ tabel sebesar 2,208 maka $\mathrm{t}$ hitung $>\mathrm{t}$ tabel $(4,068>2,208)$ dengan nilai signifikansi $>0,05$ yang berarti bahwa profitabilitas berpengaruh positif dan signifikan terhadap kebijakan dividen pada Perusahaan WholeSale/Retail Yang Terdaftar di Bursa Efek Indonesia Periode 2015 - 2019.

\section{Pengaruh Ukuran Perusahaan Terhadap Kebijakan Dividen}

Hasil dari penelitian menunjukkan bahwa variabel ukuran perusahaan tidak berpengaruh dan tidak signifikan terhadap kebijakan dividen pada Perusahaan Wholesale/Retail yang terdaftar di Bursa Efek Indonesia periode 2015-2019.

Hasil penelitian Anggraini (2015), Arjana (2017) dan Dhira (2016) yang menunjukkan bahwa ukuran perusahaan berpengaruh signifikan terhadap kebijakan dividen.

Tidak adanya pengaruh antara variabel ukuran perusahaan dan kebijakan dividen, hal ini disebabkan oleh keadaan perekonomian yang belum begitu stabil, sehingga pengelolaan dana yang dilakukan oleh perusahaan dalam menjalankan usahanya belum efektif. Laba yang dihasilkan pun tidak maksimal. Keadaan yang demikian membuat baik perusahaan kecil maupun besar akan lebih berorientasi pada pertumbuhan perusahaannya.

\section{Pengaruh Kebijakan Hutang terhadap Kebijakan Dividen \\ Hasil dari penelitian} menunjukkan bahwa variabel kebijakan hutang tidak berpengaruh dan tidak signifikan terhadap kebijakan dividen pada Perusahaan Wholesale/Retail yang terdaftar di Bursa Efek Indonesia periode 2015-2019.

Hasil penelitian ini sejalan dengan hasil penelitian yang dilakukan sebelumnya oleh Rahmawati (2017) yang menunjukkan bahwa kebijakan hutang tidak berpengaruh terhadap kebijakan dividen. Akan tetapi hasil ini bertentangan dengan penelitian Bansaleng (2014) dan Thaib (2015) yang menunjukkan bahwa kebijakan hutang berpengaruh signifikan terhadap kebijakan dividen. 
Tidak adanya pengaruh antara variabel kebijakan hutang dan kebijakan dividen, hal ini disebabkan oleh penggunaan hutang yang tinggi akan menyebabkan penurunan kemampuan perusahaan dalam membayarkan dividennya, dikarenakan sebagian besar keuntungan akan dialokasikan pada cadangan dana untuk pelunasan hutang. Perusahaan yang memiliki tingkat hutang yang rendah akan lebih memprioritaskan kesejahteraan pemegang sahamnya dengan pembagian dividen, sebaliknya jika perusahaan tersebut memiliki tingkat hutang yang besar maka perusahaan akan lebih berkonsentrasi pada pelunasan kewajibannya dibanding membagikan dividen agar dapat mencegah kebangkrutan karena tidak bisa memenuhi kewajibannya kepada pihak kreditur.

\section{Pengaruh Profitabilitas terhadap Kebijakan Dividen}

Hasil penelitian ini menunjukkan bahwa variabel profitabilitas berpengaruh terhadap kebijakan dividen secara positif dan signifikan terhadap kebijakan dividen pada Perusahaan Wholesale/Retail yang terdaftar di Bursa Efek Indonesia periode 2015-2019

Hasil penelitian ini sejalan dengan hasil penelitian yang dilakukan sebelumnya oleh Anggraini (2015), Arjana (2017), Bansaleng (2014) dan Thaib (2015) yang menunjukkan bahwa profitabilitas berpengaruh signifikan terhadap kebijakan dividen. Akan tetapi hasil ini bertentangan dengan penelitian Saputra (2013) yang menunjukkan bahwa profitabilitas tidak berpengaruh terhadap kebijakan dividen.

Adanya pengaruh antara variabel profitabilitas dan kebijakan dividen, hal ini disebabkan oleh tingginya tingkat keuntungan yang dimiliki oleh perusahan, maka perusahaan akan mensinyalkan hal tersebut kepada para pemegang saham dengan cara membagikan laba yang diperoleh dalam bentuk dividen. Pembagian dividen juga mengandung informasi perusahaan dalam kondisi baik dan dapat digunakan untuk meramalkan kondisi baik dimasa yang akan datang.

\section{Pengaruh Likuiditas Terhadap Kebijaan Dividen}

Hasil dari penelitian menunjukkan bahwa Likuiditas tidak berpengaruh dan tidak signifikan terhadap kebijakan deviden pada Perusahaan Wholesale/Retail yang terdaftar di Bursa Efek Indonesia periode 2015-2019.

Hasil penelitian Saputra (2013) yang menunjukkan bahwa likuiditas berpengaruh signifikan terhadap kebijakan dividen. Tidak adanya pengaruh antara variabel kebijakan hutang dan kebijakan dividen, hal ini disebabkan oleh likuiditas tidak hanya digunakan dalam pembayaran dividen tetapi juga dipengaruhi oleh keputusankeputusan di bidang investasi dan pembiayaan lainnya seperti pembiayaan operasional, pelunasan hutang yang sudah jatuh tempo, dan pembelian aktiva tetap. Untuk itu, perusahaan yang memiliki likuiditas yang baik tidak berarti pembayaran dividen lebih baik pula ataupun sebaliknya.

\section{PENUTUP}

\section{Kesimpulan}

Berdasarkan pengujian hipotesis, diperoleh hasil sebagai berikut :

1. Secara parsial, ukuran perusahaan tidak berpengaruh dan tidak signifikan terhadap kebijakan dividen pada perusahaan Wholesale/Retail yang terdaftar di Bursa Efek Indonesia periode 20152019. 
2. Secara parsial, kebijakan hutang tidak berpengaruh dan tidak signifikan terhadap kebijakan dividen pada perusahaan Wholesale/Retail yang terdaftar di Bursa Efek Indonesia periode 20152019.

3. Secara parsial, profitabilitas berpengaruh positif dan signifikan terhadap kebijakan dividen pada perusahaan Wholesale/Retail yang terdaftar di Bursa Efek Indonesia periode 2015-2019.

4. Secara parsial, likuiditas tidak berpengaruh dan tidak signifikan terhadap kebijakan dividen pada perusahaan Wholesale/Retail yang terdaftar di Bursa Efek Indonesia periode 2015-2019.

5. Secara simultan Ukuran Perusahaan, Kebijakan Hutang, Profitabilitas, Likuiditas berpengaruh dan signifikan terhadap kebijakan dividen pada perusahaan Wholesale/Retail yang terdaftar di Bursa Efek Indonesia periode 2015-2019. Besarnya koefisien determinasi sebesar $29,2 \%$ sedangkan sisanya sebesar $70,8 \%$ kebijakan dividen dijelaskan oleh variabel lain yang tidak diteliti dalam penelitian ini. secara parsial hanya profitabilitas berpengaruh signifikan terhadap kebijakan dividen pada perusahaan Wholesale/Retail yang terdaftar di Bursa Efek Indonesia periode 2015-2019.

\section{Saran}

Beberapa saran yang dapat dikemukakan penulis berkaitan dengan hasil penelitian ini antara lain:

1. Bagi investor, sebelum memutuskan untuk melakukan investasi terhadap perusahaan, hendaknya para investor dapat memilih kondisi perusahaan yang dapat memberikan sinyal positif dengan memperhatikan besaran ukuran perusahaannya, tingkat hutangnya, keuntungan perusahaan dan kemampuan menggunakan aset perusahaan.

2. Bagi peneliti selanjutnya dapat menggunakan faktor-faktor internal lainnya yang kemungkinan mempengaruhi kebijakan dividen selain ukuran perusahaan, kebijakan hutang, profitabilitas, likuiditas seperti Earning Per Share, Total Asset, Turn Over Ratio atau Arus Kas Bebas atau dapat memilih sektor yang berbeda untuk mengetahui perbedaan faktor-faktor yang mempengaruhi kebijakan diividen pada perusahaan-perusahaan sektor lainnya seperti perusahaan manufaktur.

3. Bagi Perusahaan, diharapkan lebih memperhatikan kinerja keuangan khususnya yang menyangkut ukuran perusahaan, kebijakan hutang, profitabilitas, likuiditas, karena tanpa mempertimbangkan rasio keuangan tersebut akan berdampak pendapatan perusahaan di masa depan terutama penurunan pembagian dividen bagi para pemegang saham.

\section{DAFTAR PUSTAKA}

Anggraini, Dita, A.D. \& Wihandaru. (2015). Pengaruh Ukuran Perusahaan, Pertumbuhan Perusahaan, Free Cash Flow, Leverage, Profitabilitas dan Struktur Kepemilikan Terhadap Kebijakan Membayar Dividen. Jurnal Manajemen Bisnis, 6(2).

Arjana, I Putu, P. H. \& Dharma, S. (2017). Pengaruh Profitabilitas, Leverage, Ukuran Perusahaan dan Corporate Social Responsibility Pada Kebijakan Dividen. E-Jurnal Akuntansi Universitas Udayana 21(3): 2021-2051. 
Dhira, Nindi, S.O, Novi, W. \& Nining, I.W. (2014). Pengaruh Laba Bersih, Arus Kas Operasi, dan Ukuran Perusahaan terhadap Kebijakan Dividen (Studi Empiris pada Perusahaan Manufaktur yang listed di Bursa Efek Indonesia). Jurnal Universitas Jember. 13(2).

Hery. (2017). Kajian Riset Keuangan. Jakarta : Penerbit PT Grasindo.

Husnan, S. \& Enny, P. (2012). Dasardasar Manajemen Keuangan. Edisi Ketujuh. Yogyakarta : UPP STIM YKPN.

Mulyawan, S. (2015). Manajemen Keuangan. Bandung : Pustaka Setia.

Musthafa. (2017). Manajemen Keuangan. Yogyakarta : Penerbit ANDI.

Rachmawati, K. (2017). Pengaruh Ukuran Perusahaan dan Kebijakan Utang terhadap Kebijakan Dividen (Studi Kasus Pada Perusahaan Properti Yang Terdaftar di Bursa Efek Indonesia (BEI) Periode 20122015).

Saputra, Bagus., D. (2013). Pengaruh Likuiditas, Leverage dan Profitabilitas terhadap Kebijakan Deviden (Studi Empiris pada Perusahaan Automotive and Components yang Listed di BEI).

Sudana, I., M. (2015). Manajemen Keuangan Perusahaan. Jakarta : Erlangga.

Thaib, C., \& Rita, T. (2015). Pengaruh Kebijakan Hutang dan Profitabilitas terhadap Kebijakan Dividen (Studi Pada Perusahaan Foods And Beverages Yang Terdaftar Di BEI Tahun 20102014). Jurnal EMBA. 3(4): 215225.
Bansaleng, R., Parengkuan, T. \& Ivonne, S. S. (2014). Kebijakan Hutang, Struktur Kepemilikan dan Profitabilitas terhadap Kebijakan Dividen pada Perusahaan Food And Beverage Di Bursa Efek Indonesia. Jurnal $E M B A, 2(3): 817-830$ 